\title{
Spectrophotometric Determination of Trace Amount of Copper(II) Ion Based on Complexation with an Anthraquinone Derivative
}

\author{
Massoud NeJATI-YAZDINEJAD \\ Department of Chemistry, Faculty of Sciences, Zabol University, Zabol, P. O. Box 98615 538, I. R. Iran
}

\begin{abstract}
The spectrophotometric determination of $\mathrm{Cu}$ (II) with an anthraquinone derivative (Alizarin Red $\mathrm{S}$ ) has been investigated. The experimental conditions, such as the $\mathrm{pH}$ of the sample and concentration of ligand, were optimized. This method is simple and sensitive for determination of $\mathrm{Cu}$ (II) ion. The interfering effects of diverse ions were investigated. Copper ion was determined by measuring the absorbance of the $\mathrm{Cu}(\mathrm{II})$-ARS complex at $510 \mathrm{~nm}$. Beer's law was obeyed over the concentration range of $0.011-0.320 \mathrm{mmol} \mathrm{dm}^{-3}$ and the detection limit $(S / N=3)$ was $0.038 \mu \mathrm{g} \mathrm{cm}^{-3}$. The relative standard deviation at $20 \mu \mathrm{g} \mathrm{cm}^{-3}$ was $1.02 \%(n=5)$. The method was applied for real samples.
\end{abstract}

(Received November 10, 2005; Accepted December 12, 2005)

\section{Introduction}

$\mathrm{Cu}(\mathrm{II})$ ion is widely distributed in foods of plant tissue and animal organs. It is an essential trace element, but is also toxic in the environment. The determination of traces of copper has received considerable attention in the battle against environmental pollution. In order to assess its accumulation or deficiency in biological and environmental samples, sensitive and accurate analytical methods are required.

In the determination of copper, various methods, including inductively coupled plasma-mass spectrometry, ${ }^{1-4}$ ion chromatography, ${ }^{5-7}$ anodic stripping analysis ${ }^{8-12}$ and atomic absorption spectrophotometry ${ }^{13-16}$ have been used. Many of these methods are either time-consuming or require complicated and expensive instruments.

Although numerous organic reagents, such as $\mathrm{PAN},{ }^{17}$ zincon, ${ }^{18} \mathrm{PAR}^{19}$ and $\mathrm{DDTC}^{20}$ have been proposed for the spectrophotometric determination of copper, none of the methods presently available are completely satisfactory.

In analytical chemistry, anthraquinone derivatives have been widely used, mainly as strong chelating agents and chromophores. These chelates are then used in selective and sensitive determination of metals. ${ }^{21}$

Therefore, an attractive alternative method that could determine trace amount of copper, rapidly and conveniently, by using Alizarin Red S (ARS) chelating agent, was researched. In this study, ARS was used to react with $\mathrm{Cu}(\mathrm{II})$, forming a colored, water-soluble complex. The reaction is very fast and the sensitivity of the reagent has been made selective by controlling the $\mathrm{pH}$ of the solution. Therefore, in this investigation an effort was made to develop a simple, selective, reproducible and sensitive method for the determination of $\mathrm{Cu}(\mathrm{II})$ in a wide range of materials.

\section{Experimental}

Reagents

All chemicals used in this experiment were of analytical grade. Deionized water was used throughout all experiments. An acetic acid-sodium actate buffer solution ( $\mathrm{pH}$ 5.0) was used. An Alizarin Red S solution $\left(4.0 \times 10^{-3} \mathrm{~mol} \mathrm{dm}^{-3}\right)$ was prepared by dissolving $0.1457 \mathrm{~g}$ of the reagent (Merck) in $100.0 \mathrm{~cm}^{3}$ of water. A stock standard solution of copper ion $\left(1.3 \times 10^{-3} \mathrm{~mol}\right.$ $\mathrm{dm}^{-3}$ ) was prepared by dissolving $0.0332 \mathrm{~g}$ of $\mathrm{CuSO}_{4} \cdot 5 \mathrm{H}_{2} \mathrm{O}$ (Merck) in $100.0 \mathrm{~cm}^{3}$ water.

\section{Apparatus}

All absorbance measurements were made with a Shimadzu UV 2100 spectrophotometer using 1-cm quartz cells. All pH measurements were made with a Metrohm $691 \mathrm{pH}$ meter. For reference method measurements, a Philips PU 9100X atomic absorption spectrometer at $324.7 \mathrm{~nm}$ was used for comparing the results.

\section{General procedure}

A $5.0-\mathrm{cm}^{3}$ volume of buffer solution, $5.0 \mathrm{~cm}^{3}$ of stock Alizarin Red $\mathrm{S}$ solution and an appropriate volume of $\mathrm{Cu}(\mathrm{II})$ were added to a $25.0 \mathrm{~cm}^{3}$ volumetric flask and made up to the mark with deionized water. The solution was left for $5 \mathrm{~min}$ and then the absorbance was measured. These spectra were recorded over the 380-660 nm wavelength range. The absorbance was measured against the blank solution.

\section{Determination of $\mathrm{Cu}(\mathrm{II})$ in real sample}

After $0.58 \mathrm{~g}$ of copper wire sample was dissolved in mixture of $15 \mathrm{~cm}^{3} \mathrm{HNO}_{3}$ and $1 \mathrm{~cm}^{3} \mathrm{H}_{2} \mathrm{SO}_{4}$, the solution was heated to drive off the oxides of nitrogen and then cooled, neutralized and diluted to $1000 \mathrm{~cm}^{3}$. Then $2.5 \mathrm{~cm}^{3}$ of this solution were taken and, using the recommended procedure, analyzed for $\mathrm{Cu}(\mathrm{II})$.

Also, $10.0 \mathrm{~cm}^{3}$ of water samples were analyzed by using the recommended general procedure.

\section{Results and Discussion}

$\mathrm{Cu}(\mathrm{II})$ reacts with Alizarin Red $\mathrm{S}$ giving a intensive red color in acidic solution. The spectral characteristic, effect of variables and foreign ions on $\mathrm{Cu}(\mathrm{II})-\mathrm{ARS}$ absorbance and applications of 


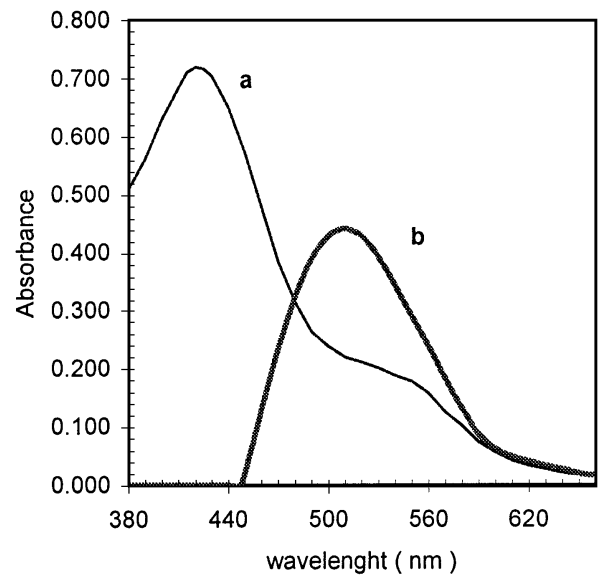

Fig. 1 Absorption spectra of (a) ARS against deionized water (b) $\mathrm{Cu}$ (II)-ARS complex against the reagent blank, both at $\mathrm{pH}$ 5.0.

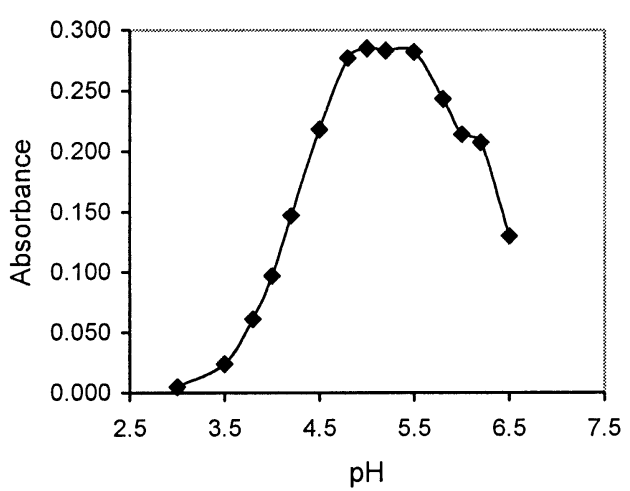

Fig. $2 \mathrm{pH}$ effect on the change in the absorbance of the $\mathrm{Cu}(\mathrm{II})$-ARS complex $\left(\mathrm{Cu}(\mathrm{II})=4.0 \times 10^{-3} \mathrm{~mol} \mathrm{dm}^{-3}\right.$ and ARS $\left.=8.0 \times 10^{-3} \mathrm{~mol} \mathrm{dm}^{-3}\right)$.

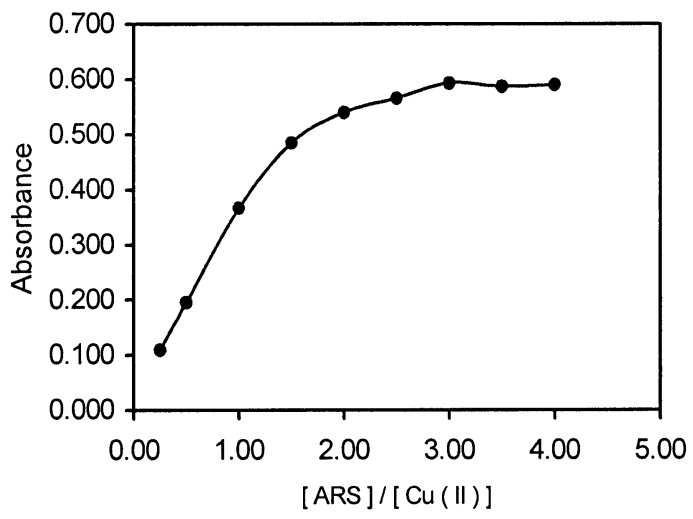

Fig. 3 Effect of the reagent concentration on the absorbance of the $\mathrm{Cu}$ (II)-ARS system at $\mathrm{pH}$ 5.0.

the system are discussed below.

\section{Spectral characteristics}

The absorption spectra of the $\mathrm{Cu}(\mathrm{II})$-ARS complex and ARS show a maximum absorption at 510 and $420 \mathrm{~nm}$, respectively (Fig. 1), and the absorbance of the complex showed the maximum values for $\mathrm{pH}$ values in the $4.8-5.2$ range (Fig. 2). In more acidic or more alkaline solutions, the absorbance decreased because of incomplete complex formation and
Table 1 Tolerance limit of foreign ions $\left(\mu \mathrm{g} \mathrm{cm}^{-3}\right)$

\begin{tabular}{lrlr}
\hline \multicolumn{1}{c}{ Cation } & Conc. & \multicolumn{1}{c}{ Anion } & Conc. \\
\hline $\mathrm{Na}^{+}, \mathrm{K}^{+}$ & 1000 & $\mathrm{~F}^{-}, \mathrm{Cl}^{-}, \mathrm{Br}^{-}$ & 1000 \\
$\mathrm{Mn}^{2+}, \mathrm{Zn}^{2+}, \mathrm{Mg}^{2+}, \mathrm{Ba}^{2+}, \mathrm{Ca}^{2+}, \mathrm{Cd}^{2+}$ & 1000 & $\mathrm{SCN}^{-}$ & 500 \\
$\mathrm{Ni}^{2+}$ & 550 & $\mathrm{NO}_{3}^{-}$ & 700 \\
$\mathrm{~Pb}^{2+}, \mathrm{Co}^{2+}$ & 500 & Acetate & 2000 \\
$\mathrm{Fe}^{3+}, \mathrm{Cr}^{3+}$ & 500 & Citrate & 200 \\
$\mathrm{Sn}^{4+}$ & 1000 & Oxalate & 1000 \\
\hline
\end{tabular}

Table 2 Determination of $\mathrm{Cu}$ (II) in real samples $\left(\mu \mathrm{g} \mathrm{cm}^{-3}\right)$

\begin{tabular}{ccc}
\hline Sample & Reference method & Proposed method $^{\mathrm{a}}$ \\
\hline 1 & 57.17 & $56.28 \pm 0.08$ \\
2 & 51.75 & $51.62 \pm 0.05$ \\
\hline
\end{tabular}

a. Mean of five-determination \pm relative standard deviation.

Table 3 Determination of $\mathrm{Cu}(\mathrm{II})$ added to a water sample $(\mu \mathrm{g}$ $\left.\mathrm{cm}^{-3}\right)$

\begin{tabular}{cccc}
\hline Sample & Spiked & Measured & Recovery, \% \\
\hline Tap water $^{\mathrm{a}}$ & 10 & 9.8 & 98.0 \\
& 20 & 20.1 & 100.5 \\
River water $^{\mathrm{a}}$ & 40 & 40.8 & 102.0 \\
& 10 & 10.3 & 103.0 \\
& 20 & 20.4 & 102.0 \\
& 40 & 40.7 & 101.8 \\
\hline
\end{tabular}

a. The sample contained no detectable $\mathrm{Cu}(\mathrm{II})$.

hydrolysis of the complex. A buffer solution of acetic acid-acetate solution ( $\mathrm{pH}$ 5.0) was chosen for subsequent studies.

The stoichiometric composition of the complex was studied under the established experimental conditions by the molar-ratio method. ${ }^{22}$ This method showed that the composition of the complex is 1:2 (Fig. 3).

\section{Effect of time}

The complexation reaction is very fast. A constant maximum absorbance was obtained just after dilution to volume, and remained unaltered for $24 \mathrm{~h}$.

\section{Calibration graph, precision and detection limit}

Beer's law is obeyed over the concentration range of 0.011 $0.320 \mathrm{mmol} \mathrm{dm}^{-3}$ at $510 \mathrm{~nm}$. The molar absorptivity and correlation coefficient were calculated to be $9.37 \times 10^{3} \mathrm{dm}^{-3}$ $\mathrm{mol}^{-1} \mathrm{~cm}^{-1}$ and 0.9997 , respectively. The precision of the present method was evaluated by the determining concentration $\mathrm{Cu}$ (II) at the $20 \mu \mathrm{g} \mathrm{cm}^{-3}$ level (analyzed at least five times). The relative standard deviation $(n=5)$ was $1.02 \%$, indicating that this method is highly precise and reproducible. The detection limit (3-times the standard deviation of the blank) ${ }^{23}$ for $\mathrm{Cu}$ (II) was found to be $0.038 \mu \mathrm{g} \mathrm{cm}^{-3}$.

\section{Interferences}

To assess the usefulness of this method, the effects of foreign ions, which often interfere with the determination of $\mathrm{Cu}$ (II) were studied. The tolerance limits given in Table 1 are the concentrations that cause an error of less than $\pm 5.0 \%$ in the 
absorbance of a $30 \mu \mathrm{g} \mathrm{cm}^{-3} \mathrm{Cu}$ (II) solution. Some interfering ions may be masked using proper masking agents. ${ }^{24}$ The tested results were as follows: $1 \mathrm{~cm}^{3}$ of $1000 \mu \mathrm{g} \mathrm{cm}^{-3}$ tartarate could mask $500 \mu \mathrm{g}$ of $\mathrm{Co}(\mathrm{II})$ and (III), $\mathrm{Mn}^{2+}$ and $\mathrm{Fe}^{3+}$. For this reason, the selectivity of the proposed method is greatly improved.

\section{Applications to real samples}

To evaluate the analytical applicability and to check the accuracy of the proposed method, we applied it to the determination of $\mathrm{Cu}$ (II) in two electric copper wire samples and tap water and river water spiked with $\mathrm{Cu}(\mathrm{II})$. The obtained results are summarized in Tables 2 and 3, respectively. This method is in good agreement and comparable in accuracy and precision with reference method (atomic absorption spectrometry $)^{25}$ and is very quantitative.

\section{Conclusion}

Alizarin Red $\mathrm{S}$ is a good spectrophotometer reagent for the determination of $\mathrm{Cu}(\mathrm{II})$. The method is very simple, sensitive and more selective than most reported methods. The results obtained by the recommended method are in excellent agreement with those determined by FAAS. The procedure is suitable for the determination of industrial copper products and real samples.

\section{References}

1. T. Kato, S. Nakamura, and M. Mirita, Anal. Sci., 1990, 6, 623.

2. A. O. Jacintho, E. A. G. Zagatto, and H. Bergamin, Anal. Chim. Acta, 1981, 130, 243

3. E. A. G. Zagatto, A. O. Jacintho, and F. F. J. Krug, Anal. Chim. Acta, 1983, 145, 169
4. K. K. Falkner and J. M. Edmond, Anal. Chem., 1990, 62 1447.

5. C. Lin, C. Lu, C. W. Huie, and M. Yamada, Anal. Sci., 2003, $19,557$.

6. N. Cardellicchio, S. Cavalli, P. Ragone, and J. M. Riviello, J. Chromatogr., A, 1999, 847, 251

7. O. V. Krokhim, O. V. Kuzina, and H. Hoshino, J. Chromatogr., A, 2000, 895, 255.

8. J. F. Staden and M. C. Matoetoe, Anal. Chim. Acta, 2000, $411,201$.

9. J. Ruzicka and E. H. Hansen, Anal. Chim. Acta, 1978, 99, 37

10. A. Hu, R. E. Dessy, and A. Graneli, Anal. Chem., 1983, 55 , 320 .

11. L. Anderson, D. Jagner, and M. Josefson, Anal. Chem., 1982, 51, 1371

12. J. Janata and J. Ruzicka, Anal. Chim. Acta, 1980, 139, 105.

13. K. Cundeva and T. Stafilov, Anal. Lett., 1997, 30, 833.

14. W. R. Wolf and K. K. Stewart, Anal. Chem., 1979, 51, 1201.

15. K. Fukamachi and N. Ishibashi, Anal. Chim. Acta, 1980 , 119,383

16. Z. Fang, S. Xu, and S. Zhang, Anal. Chim. Acta, 1984, 164, 41

17. M. Thakur and M. K. Deb, Talanta, 1999, 49, 561.

18. P. Richter, M. I. Tral, and A. E. Tapia, Analyst, 1997, 122, 1054.

19. A. N. Arauja and R. C. C. Costa, Talanta, 1999, 50, 337.

20. T. Blanco, N. Maniasso, and M. F. Gine, Analyst, 1998, $123,191$.

21. A. N. Diaz, Talanta, 1991, 38, 571.

22. J. D. Dick, "Analytical Chemistry", 1972, McGraw-Hill Inc., 607.

23. J. N. Miller and T. C. Miller, "Statistics and Chemometrics for Analytical Chemistry", 2000, Pearson Edu, Ilarlow.

24. Z. Marczenko, "Separation and Spectrophotometric Determination of Elements", 1986, Ellis Horwood, 76.

25. “Аnnual Book of ASTM Standards", 2002, Vol. 11, 743. 